\title{
Management Shadowing Program: An Incubator for Prospective Managers in the Tourism and Hospitality Industry
}

\author{
Gölge Yönetici Programı: \\ Turiżm Sektörü İçin Geleceğin Yöneticilerini Yetiştiren Kuluçka Programı
}

\section{Demet CEYLAN * Duygu ÖZYEŞiL **}

\begin{abstract}
The hospitality industry needs qualified work-ready graduates with skills but unfortunately tourism students are changing their career paths outside tourism and/or cannot obtain a managerial perspective. The Management Shadowing Program joins up the dots between academia, graduates and practitioners with real-life experiences from the management perspective, which opens a new window of opportunity for tourism graduates in a preference towards a career in tourism. This program enables theoretical in-class learning and summer internship practical experience at a managerial level, leading to the utilization of data within practical contexts. The holistic multiple explanatory case study method utilized in this study reveals how industry-academia cooperation can effectively produce prospective managers of hospitality. Semi-structured interviews, focus group, weekly report content analysis, participant observations and questionnaires were used for the triangulation of data collection and analysis. The aim of this study is to propose a model for a Management Shadowing Program that can be used as an incubator for prospective graduates with the clear target of developing their managerial skills via experiential learning and creating a talent pool for the industry, as well as assurance of curriculum for academia and to evaluate the outcomes of the program from the perspectives of both alumni and the sector.
\end{abstract}

Keywords: Management Shadowing, Academia and Tourism Industry Partnership, Mentor - Protégé Learning-Teaching Method, Developing and Retaining Talents in Tourism and Hospitality

Öz: Konaklama endüstrisi, yetenekli, işe hazır ve nitelikli mezunlara ihtiyaç duyarken maalesef, turizm öğrencileri kariyerlerini turizm dışındaki sektörlere yöneltiyorlar ve/veya eğitimleri sırasında yönetimsel bakış açısı elde edemiyor. Gölge Yönetici Programı, turizm mezunları için turizm alanında kariyer yapmayı tercih etmeleri için yeni bir firsat penceresi açmaya yöneliktir ve mezunlar, akademisyenler ve uygulayıcılar arasındaki noktaları yönetim perspektifinden gerçek hayat deneyimleriyle birleştirmektedir. Program, yönetsel düzeyde sınıf içi öğrenme ve yaz staji pratik tecrübelerini birleştirmeyi sağlayarak gerçek hayatta yöneticilik deneyimleri edinilmesine olanak sağlar. Bu çalışmada kullanılan bütünsel çoklu açıklayıcı vaka çalışması yöntemi, sektör-akademi işbirliği ile potansiyel yöneticilerini nasıl etkili bir şekilde üretebileceğini ortaya koymaktadır. Veri toplama ve analizlerinin çeşitlendirilmesinde yarı yapılandırılmış görüşmeler, odak grup çalışması, haftalık rapor içerik analizi, katılımcı gözlemleri ve anketler kullanılmaktadır. Bu çalışma, Gölge Yönetici Programının amacı sektör için yetenek havuzu yaratmak, akademi için müfredatın sektörün ihtiyaçlarına uyumunu sağlamaya yönelik bir model önerisi geliştirmeyi ve mezunların yönetsel beceriler geliştirmek için firsat sunan bir yönetici kuluçka programnı hem müstakbel mezunlar hem sector gözünden programın başarısının değerlendirilmesidir.

Anahtar sözcükler: Gölge Yönetici Programı, Akademi- Turizm Sektörü İş Birliği, Usta-Çırak ÖğrenmeÖğretme Metodu, Turizm Sektöründe Yeni Yetenekleri Yetiştirme ve Tutundurma

\footnotetext{
* Lecturer, Antalya Bilim University, Faculty of Tourism, Antalya. demet.ceylan@antalya.edu.tr, https://orcid.org/0000-0003-3948-8309

** Antalya Bilim University, Faculty of Tourism, Antalya. duygu.ozyesil@antalya.edu.tr, https://orcid.org/0000-0002-0163-9530
} 


\section{Introduction}

Hospitality is also known as "the people" industry due to its labor intensive nature. Service production is quite interesting, as the customer is a part of the production process and also the service is both produced and consumed simultaneously. Combining the human factor on both the production and consumption sides of service brings infinite combinations of service. Lack of human encounter in theoretical work in class learning may partially be compensated for through internship program experiences at working level. But how can prospective leaders and managers of tourism be educated at tourism higher education with only limited working level internship experiences? Academia must stay in close cooperation with the tourism sector practitioners and provide platforms for prospective graduates to step into the shoes of managers, and to put on management glasses before graduation, in order that theoretical learning and working level internship experiences can be merged at a management level. The scope of this study is to share the experiences and findings of the Management Shadowing Program application targeted to develop managerial skills of tourism higher education students prior to their graduation.

The hospitality industry is looking for work-ready graduates, having relevant experience and trained with adequate skills. A skilled, enthusiastic, and committed work-force is vital to the success of the industry (Wexley \& Baldwin 1986; Mullins 1993; Adam \& Maxwell 1995; McEwan 1995; Purcell \& Quinn 1996; Garavan et al. 1999; Kusluvan \& Kusluvan 2000; Mabey 2002; Ceylan 2017).

The hospitality industry looks for personal skills in communication, adaptability, and leadership; the ability to function within a team; interpersonal skills like speaking, writing, and negotiating; work ethics; innovative and creative thinking; managing and efficiently using upto-date technological tools and understanding the impact of globalization (Robert 1993; Anafarta \& Cizel 2003; Martin \& McEvoy 2003; Littlejohn \& Watson 2004).

It is evident that the sustainability and the development of the tourism industry depends upon a talented and educated work force, while tourism higher education may not be yielding the desired output. Although it is acknowledged that internship experience is an essential part of tourism education, misconducted internship experiences of tourism students is reported to be a reason why tourism students do not want to work in the tourism industry after graduation. Tourism industry lacks recruiting as well as retaining talents (Kusluvan \& Kusluvan 2000; Littlejohn \& Watson 2004; Aksu \& Köksal 2005; Roney \& Oztin 2007; Unur \& Köşker 2015; Daskin 2016).

In tourism higher education there are several work integrated programs. Sandwich year application within a 3 year tourism higher education provides the opportunity for students to study one year, work one year and study one year. The middle year of this sandwich program is predefined to cover more than one department at working level. Similarly the four year tourism higher education requires two summer internships in different departments during the summers of the sophomore and junior years. The internship and sandwich year are similar to each other in terms of responsibility and capability. Both the summer internship and the sandwich year students are expected to perform manual work to gain bottom up experience from the senior employees. The knowhow transfer is conducted by applying predefined repetitive tasks. Students are not expected to solve problems, be creative or to manage people. Students or in other words the interns are expected to inform their superior when they face a situation not defined, or out of the ordinary. Interns are commonly regarded as low cost man-power by the industry for repetitive tasks where the learning process takes a few days and work force production continues in all season (Kusluvan \& Kusluvan 2000; Anafarta \& Cizel 2003; Aksu \& Köksal 2005; Zopiatis \& Theocharous 2013).

Management trainee programs are another opportunity for experiential learning towards management levels. Management trainees are subject to predefined programs of 18-24 months 
in different departments, yet are similar to the internship and sandwich year applications, the management trainees are called "trainee" and start from the bottom level of a department. By the time trainee develops an understanding of the department's work, it is time to move to the next department in the program. Management trainee programs are designed to provide an understanding of the service chain, rather than developing the trainee's managerial skills (McKercher et al. 1995; Roney \& Oztin 2007; Huang \& Lin 2010; Spanjaard et al. 2018).

Littlejohn \& Watson (2004) state the importance of close liaison between industry and higher education. The call for the co-operation of stakeholders enables the redesigning of hands on training from managerial level employment opens new windows for tourism graduates and can increase the willingness of tourism graduates to work within the industry, and, at the same time meet the expectation of the industry for career-ready graduates.

Spanjaard et al. (2018) emphasises prospective graduates must be at graduation careerready, which is further advanced than being work-ready. Graduates must have a longer term perspective of their career, rather than a focus on their first post-graduate employment. Exposing prospective graduates to real life situations where immediate decision making enables the development of soft skills advances their prospective career prospects. Implementing experiential learning into curricula and designing an incubator for career ready graduates to meet the expectations of industry requires attention on the capabilities of the student and a focus on relevance in employability skills.

Raybould \& Wilkins (2005) have identified what hospitality managers expect in comparison with what students think hospitality managers would value and found that inter-personal skills, problem solving and self-management skills are the priority skills which in the recruitment phase hospitality managers look for.

Kolb and Lewis (1986) propose the utilization of the experiential learning theory of Dewey as the framework for studying the critical links between academia, practitioners and the personal development of program participants. This method in two ways brings the learner and learned closer: (i) firstly by encouraging the participant to reflect on actual experiences and combine these experiences with the abstract theoretical education received in class to make the concepts become real, and (ii) secondly by encouraging participants to act, take the initiative and the responsibility for the decisions they make. Experiential learning in the real sector constructs a four dimensional learning environment and leads to the acquisition of the necessary skills to make the decision, realize their own potential and develop their personal attitudes towards the industry and profession. Experiential learning provides the opportunity for the learner to apply knowledge and skills to solve real-life problems through firsthand experience, ensuring the sense of accomplishment and self-esteem due to the personal interaction leading to emotional involvement.

Experiential learning is the path of transformation from credit hours to competencies. Academia can contribute to the more complex intellectual development of students rather than developing verbal skills and providing theoretical information in class. Experiential learning helps students to understand and to cope with real-life tasks imposed by the working environment (Chickering 1977). Miettinen (2000) compares Dewey's and Kolb’s experiential learning and states the wide utilization of the concept within managerial training and adult education with its dual characteristic of real-life experience and reflection.

Bower (2014) describes experiential learning as a method of combining academic knowledge with practical skills by discovering, processing, applying, information, and the reflection of this knowledge in real-life situations. The method encourages the students to connect theoretical in class teaching with practical experiences. 
Dewey (1938) has described the pillars of experiential learning as:

- The Social environment is the setting where students, industry practitioners and academia meet in real life.

- Knowledge is constructed based upon experiences within the social environment and provides the context for the theoretical information obtained in class.

- The readiness and capabilities of the learner plays an important role in the quality of the experience. The accumulated experiences enable students to join together the theoretical education and the practical experiences.

- The teacher's role is to organize the content and facilitate the actual experience towards the desired learning outcomes

- The outcome of learning is the knowledge acquired via experiences which enables students to apply this knowledge within different circumstances.

Dewey (1938) focuses on the training students' problem solving abilities employing pre-tested formulas for reoccurring service encounters whereas Counts (1978) goes further, by proposing training the students for constructing the future through creative new solutions in addition to solving the problems of today with through previous experiences. Both believed in experiential learning as a tool to enhance classroom learning and strongly believe in the potential of education as incubator in producing change makers.

As the literature suggests, the managerial skills required by the sector cannot be acquired through classroom teaching and consequently the experiential learning process is strongly recommended. It is evident that the hospitality sector requires graduates with prospective management capabilities and graduates are enrolling in tourism higher education for management perspectives and yet the academia sector partnership providing the platform for prospective graduates to test their wings by combining theoretical classroom learning with real life experiences at management level are limited. Summer internships, sandwich year applications, management trainee programs provide experiential learning at production level rather than providing any managerial perspective.

This study proposes a model for prospective tourism higher education students in managerial skill development and also provides insights into best practice applications for managerial skill development. And it presents an evaluation of the Management Shadowing Program by students and sector, such as how students can benefit from the program in their personal managerial skill development and how the sector can benefit from recruiting qualified human resources. The findings from this study present admitted outcomes for both students and the sector. The aim of scholars to understand the necessary ingredients leading to management positions and increasing those ingredients in the curriculum, while keeping close cooperation with the sector to understand the momentum of changes in the industry from first hand experiences and the demands of sector managers.

\section{Study Instrument}

The Management Shadowing Program utilizes experiential learning theory and provides a social environment where students are encouraged to test their wings through first hand experiences, while with a safety net of experienced managers of partner companies. The program was developed by Antalya Bilim University and integrated into the curricula at last spring semester before graduation as an area elective course.

The Management Shadowing Program integrates classroom learning, technical knowledge, personal development and work experience under the roof of experiential learning at managerial level. Students are required to attend the lessons at campus 3 days a week, and work in 3 days at the partner companies as shadow of a department manager for a period of 13 weeks. When the 
days are sunny and calm the shadow is in front and making the decisions on day-to-day issues which are reviewed and approved by manager. When the day is neither sunny nor calm, the manager leads the process and the shadow follows in the footsteps and observes how managerial decisions are made. As the shadow managers are free from professional blindness, time pressure or budget limitations, the partner company benefits from the open minded approach of the shadow managers. The fresh ideas and questions raised by the shadow manager enables managers to gasp new business ideas as well as the scrutiny of "old" ways of conducting business (Ceylan 2017).

The selection criteria for the partner company and manager are: (i) active involvement in the tourism and hospitality industry, (ii) a company culture open for learning and open to the fostering exchange of ideas; (iii) the time and resources of the manager and, most importantly, (iv) managers who are enthusiastic and excited about participating in a program different from the good old summer internship. The potential clash of managers without formal tourism education mentoring a prospective tourism high education graduate is gently framed during the nomination of managers within the partner company.

The selection criterion for the students are simple, (i) getting a job offer from the partner companies and (ii) assuring time availability for Thursday, Friday and Saturday. A GPA of 2 out of 4 is the minimum requirement for graduation at any university in Turkey as per the regulations of the Turkish High Education Council and its up-to the student to decide if s/he is ready to risk graduation date due to failure in any other course or due to a low GPA. Taking the risk of a delayed graduation and/or enrolling in spring semester courses in earlier years to create space for the Management Shadowing program at the last year, is the first managerial decision students make.

For summer internships student have had the interview with HR department of companies active in tourism and hospitality industry so they are aware of the application, recruitment and acceptance process. But the Management Shadowing Program placement process is the first real job interview experience for the students where they have the chance to choose as much as to be chosen. This interview process enables both the shadow and the manager to meet and greet each other face to face. The opportunity to conduct interviews directly between candidate shadows and managers is an important aspect of the placement process. When a candidate shadow receives more than one offer, the shadow chooses the manager s/he wants to work with based upon these face to face interviews.

\section{Implementation Process}

The implementation of the Management Shadowing Program involves the following stages for students:

1. Program presentation to students

2. Training in CV writing techniques

3. Training in the recruitment process and in interview techniques

4. Announcement of positions with respective qualifications required similar to a job vacancy advertisement per company

5. Job interview with managers who will participate in MPS

6. Placement (3 rounds)

7. TRM 452 Management Shadowing course syllabus requires: opening/closing questionnaires, weekly reports, focus group discussions and ad hoc interviews for grading. The syllabus also requires students to attend 2 internal business meetings, 2 external business meetings and 2 job interviews at the partner company and evaluate these meetings/interviews together with their managers. Preparing and making at least one presentation is strongly recommended. 
8. TRM 452 Management Shadowing course is not open for free registration of students. The placed students' names are delivered to student affairs by the course instructor for admission. In the catalogue of courses this is the only course where "course selects the student”.

The process for the partner companies includes the following stages:

1. Nomination of partner companies

2. Meeting with HR and/or GM of partner companies for the nomination of departments, managers, and the number of potential placements

3. Execution of partnership memorandum for the Management Shadowing Program

4. Invitation of partner companies for face to face interview with the candidate shadow managers

5. Placement of students by 3 job offer rounds. When a student receives more than one offer at the first round, the student selects the manager/ company and the positions are filled in second and third rounds. Both the students and the partner companies strive for the best candidates/managers.

6. Opening/closing questionnaires as well as regular formal/informal meetings with individual/group of managers is included within the partnership protocol.

\section{Method}

This is a multiple holistic explanatory case study evaluating managerial skills development and observing essential skills leading to the position of manager. The 2017 Spring implementation was with 8 tourism students (4 non-Turkish), 10 managers, 3 partner companies, and a 12 weeks period; which was enlarged to 17 students (2 business and 15 tourism; 8 non-Turkish), 17 managers, 6 partner companies and a 13 week period in Spring 2018.

In order to reach the maximum coverage, a variety of methodologies such as weekly report document review, literature review, structured questionnaire, semi-structured interview, focus group methods are applied and a variety of sources such as: academia, literature, students, managers, sector experts are utilized to investigate the concept in depth (Gunbayi 2018).

The opening questionnaire for the managers and their shadows collected their expectations from Management Shadowing Program, the reason for participation, why they have chosen this shadow/manager and an open ended question about their opinion regarding the program.

The closing questionnaire for the shadows and the managers assesses the effectiveness of Management Shadowing Program, collects suggestions for improvement and recommendations to future shadows and the managers. The quantitative evaluation of the closing questionnaire both for the shadows and the managers is presented in the following section.

Weekly reports of shadows are used as tool to:

- Keep close relation with the shadow and to facilitate experiences leading to enhanced learning outcomes

- Ask questions to enhance their personal development process and give hints or guidance regarding business success

- Provide opportunity to reflect and digest through questions rather than answers

- Build self-confidence and encourage the taking of initiative and responsibility

\section{Study Setting}

Antalya Bilim University is a young institution open to contemporary methods of teaching and nurturing programs with relations with industry. Antalya is the tourism capital of Turkey with more than $400 \mathrm{~km}$ of Mediterranean Sea coastline hosting 46,6\% of the total bed capacity of the country (Personal email contact with E. Karabulut, chief editor of the Tourism Databank 2017 
bed capacity report). The school of tourism located in the heart of tourism provides the perfect platform for industry - academia cooperation. In addition to the advantageous location of the university and the open minded approach of the faculty, there is another factor which facilitates tailor made programs. This final ingredient is the number of students per faculty member enabling the close monitoring of each student, not only in class, but also during the course of their summer internships and enhancing the personal development of the students.

The curriculum of the School of Tourism is designed to provide in-class opportunities for projects and presentations, combined with field trips, as well as guest speakers from the industry. The syllabus of each year is designed to enhance more project work and close contact with industry and with fewer exams in the classroom as the year of education advances. During the last year at school students have already developed a network in the industry, not only during their summer internships but also due to project works and cross visits. Students are encouraged to make at least one of the compulsory summer internships abroad for the cross polarization of best practices.

Antalya Bilim University School of Tourism and the tourism industry in Antalya, provides the ecosystem for developing a contemporary program through one of the oldest methods called mentor - protégé teaching and a learning style in line with experiential learning practices as a solution to encourage tourism students to pursue careers in the tourism industry and become a change maker within the earliest possible time frame with their managerial skills acquired through the Management Shadowing Program.

\section{Model proposal}

Tourism higher education requires hands-on training enhanced by summer internships. It is important to build up both knowledge and experience parallel to each other. Students at Antalya Bilim University receive classroom learning style, including role playing in the class room for the first 4 semesters and obtain initial hands on experience during summer of their sophomore year. This first internship is designated for more manual and repetitive tasks where students observe the pyramid of the service chain from bottom up and also gain manual experience. The junior year education is specially designed to guide students to sector for term projects where students base their projects to summer internship work experience and more importantly the students start using their sector network that they obtained during their summer internship. In order to ensure prosperous internship experiences the students receive several extracurricular training such as $\mathrm{CV}$ writing techniques, recruitment interview techniques, internship guidelines training. During their junior year students are requested to combine their internship experiences into classroom learning with projects to present the different experiences of students to each other and to learn from each other's experiences. The second internship taking place after the junior year enables students to obtain experience in a different department and/or if same department in more managerial tasks and with less manual repetitive tasks. Students receive a refreshment of CV writing, interview techniques and internship guidelines training during their junior year. The curriculum of Antalya Bilim University gradually replaces the generic courses with specialized courses as the years of education increases. The first year curriculum is fixed for all students and from their sophomore year both area and non-area elective courses are introduced. The senior year curriculum has the minimum compulsory and maximum elective courses, enabling students to specialize in the areas they desire and/or to taste different aspects of the industry. The curriculum of Antalya Bilim University has fewer exams and more projects and presentations as the number of years of the student's education increase. The Management Shadowing Program is the final point before graduation where students are acting as part time student and part time shadow manager combining and balancing school, work and private life. Prior years' class room learning, internship experiences, term projects and presentations are 
embedded into the curriculum preparing the prospective graduates to test their wings within the Management Shadowing program during the last spring semester before graduation as in the model presented below.

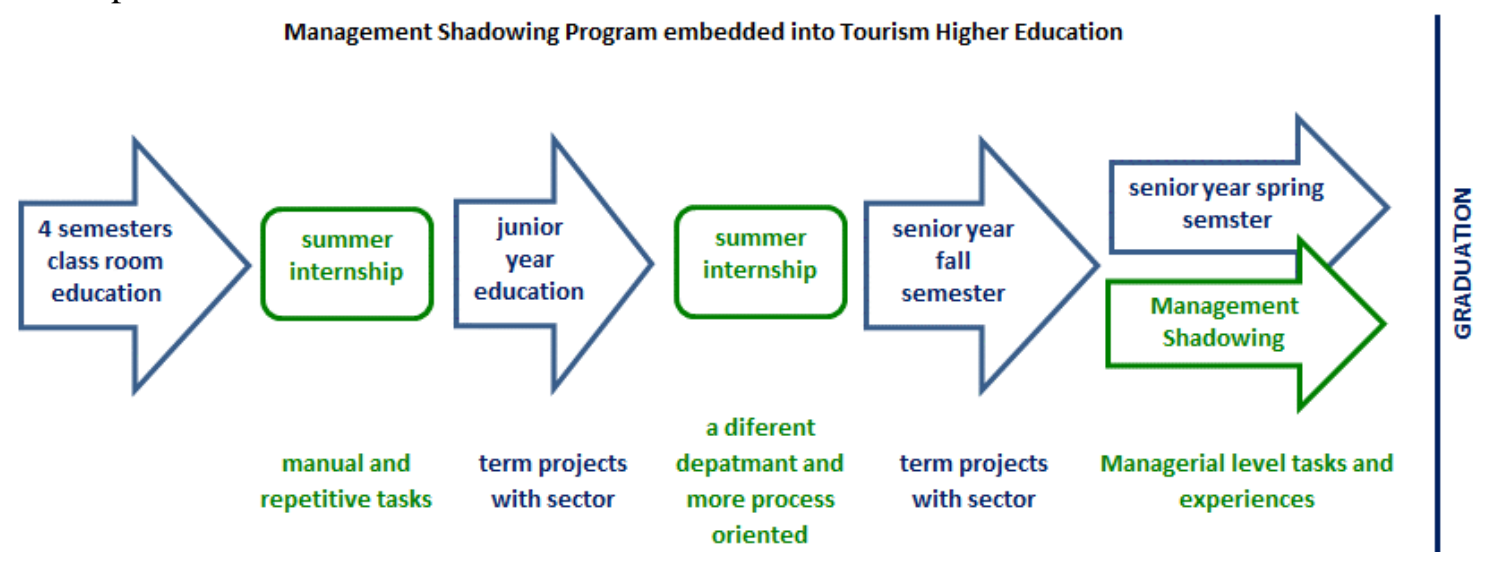

Fig. 1. Management Shadowing Program Model

\section{Validity and Reliability}

Construct validity is assured through triangulating the data collected from multiple sources (shadows, managers, HR department of partner company) as well as from the weekly reports used to generate the chain of evidence for the experiential learning outcomes. The internal validity of the study is sustained through the causal relationship explanatory assessment based upon theoretical learning in class, practical experience obtained during the summer internships and through the Management Shadowing Program experiences at managerial level. External validity is assessed by analytical generalization of the experiential learning expected outcomes and the achieved learning outcomes.

Reliability is assured through (i) observers at each stage (faculty members as well as managers at the partner companies) and (ii) clear documentation of processes and procedures of the program. As there is one evaluator of the program, intra-rater reliability is mitigated by receiving weekly reports by e-mail (same medium) without personal contact and a certain time frame devoted to weekly report evaluation and feedback to each shadow to assure the objectivity of evaluation and feedback. Structured and semi-structured questionnaire evaluation confirmed by more than one academician, while the focus group is observed by other academicians, and one-to one meetings are documented.

Weekly reports form the largest source of information as they are repeated 13 times during the course of the program. Dependability of weekly report content analysis, in other words the stability of data over time, for different weeks / participants / partner company / manager is assured by written reports following week by week answering the same questions regarding the minimum program requirements, as well as the ad hoc comments of the shadows. The weekly report is a semi-structured tool to collect reliable data. To assure the objective evaluation of the weekly reports, the structure of weekly report is designed as frame consisting of 2 internal meetings and related evaluation; 2 external meetings and related evaluation; 2 job interviews and related evaluation are the minimum requirements for the weekly report. Further open ended questions of "what was interesting this week, what was funny this week, presentations contributed/made this week and other comments are asked for, to encourage the shadows to give insightful information concerning the working environment. The context of each working environment shall be kept at perspective when evaluating the structured parts of the weekly 
report and this is important for fairly and accurately showing the program outcomes per shadow per company (Lincoln \& Guba 1985; Williams et al. 1999; Polit \& Beck 2012; Elo et al. 2014).

Ethical consideration about protecting the private information of the shadows and the confidential information of the partner companies are strictly undertaken. All participants are informed that commercially confidential data shall not be shared or reported and the private comments of the participants are not to be shared with names or are not shared at all. Managers provide their consent through a cooperation protocol and students provided their consent through the syllabus prior to the commencement of program.

\section{Findings}

The study findings indicate that both the shadows and the managers have quickly adapted to the program and both parties have cooperated with enthusiasm. Both the managers and the shadows recommended the students to enroll in this program and to initiate their management shadowing program during their summer internships of the sophomore and junior year.

Junior year students who are interested in MSP have enrolled for more courses during the spring semester to reduce the curriculum burden of the eighth semester and so have more time for the Management Shadowing Program. The side effect for younger students is a clear indication of the development of time management and organization skills long before enrollment into the Management Shadowing Program.

Also the students commit to enhance the quality of the second summer internship where students seek the opportunity of creating their own Management Shadowing Program for the eighth semester, which indicates the development of planning, networking, organisation and coordination skills. Three of the shadow managers in 2018 have generated their Management Shadowing Program job offers due to their successful internship program with the same manager and/or company as previously.

The focus group at closing in both years have been insightful as all the shadows provided suggestions for improvements or assured the adequacy of the current implementation. The following comments and recommendations of the shadow managers obtained from the focus group and the open ended questions of closing questionnaire are outstanding:

"We did not work for the hours. We worked for the tasks and achieving results"

"I was so embarrassed. How could I have done such a mistake? Now I understand that the experience is priceless".

"The first day warm welcome with a ready to work desk made me feel accepted and encouraged me to achieve".

"This program helps designing career plan and creating network. Shadows can observe how a manager organizes his day and makes decisions".

"Show your willingness to be a part of the team. Do not feel like a stranger with your manager; drink coffee, talk, share your ideas, try to learn from your manager. After all s/he is a human and has interest, hobbies. I really enjoyed spending time with my manager".

"Be proactive, do not hesitate to initiate some work or offer your ideas, be ready to do clerk jobs as well to help your manager and learn the routines as well".

Below are listed a few comments of the managers obtained from the closing questionnaire open ended questions which highlight the success of the Management Shadowing Program:

"Stepping outside the classical internship boundaries is exciting and revitalizing".

"If managers would like to give a meaningful answer to someone asking "what have you done for the future of our country?" do not miss the opportunity to say "I have worked to be the role model of many prospective managers". 
"The reason for me to join this program is to see the current process through a fresh eye".

"Clash of current managers having less school years versus 4th year tourism students casts a light on adaptation problems".

The qualitative interviews indicate the following outcomes for shadows:

- Learning / Enhancing their knowledge about professional life; office rules; punctuality; dress code; meeting ritual; formal and informal reporting structures; data flow; tone of communication with peers, managers, customers; communication skills; negotiation skills; problem solving skills; ability to be flexible and adaptive.

- Changing attitudes: in the work environment the shadow observes, practices and learns how to manage attitudes (his/her own as well as others).

- The development of decision making skills; the shadows collect/prepare daily/ periodic reports and make/propose decisions for simple daily tasks.

- The development of independent work performance (accuracy of work, timeliness of work, scope of work output).

- Learning how to use periodic information for identifying red flags in business and to understand the cause-effect relationship in the service chain.

- Development of time management skills.

- Career management: identifying strong and weak points for designing their career path in the hospitality industry.

- Developing an understanding of how organizations operate and to gain a managerial perspective.

- Meeting with sector experts and networking enabling immediate and future career opportunities, as well as obtaining firsthand information about the sector.

- Gain valuable knowledge and skills (spoken communication, written communication, teamwork, critical analysis, organizational skills, presentation skills, the application of knowledge).

Management Shadowing Program outcomes for the mentor and the sector are:

- Fresh ideas: as the shadows are not professionally blind yet, questions lead to scrutinization by eliminating excess loops or the creation of new shortcuts.

- Up-to-date technological ideas: as the shadows are highly advanced in technology, technological solutions for faster and more effective communication and calculation.

- Headhunting: attracting, recruiting and retaining highly talented students right after graduation is the duty of every HR department.

- Day-to-day interaction with a young prospective colleague brings the energy of youth to work place

- Creative ideas leading to: customer satisfaction, cost saving, revenue increase or generation, assuring of reputation, mitigating financial, legal or social risks, easing or tightening with processes undergoing scrutiny.

- First hand selection of students prior to graduation with a 3 month test period

The outcomes of the Management Shadowing Program for scholars are:

- Staying close to the industry enables academia to adjust or update the curriculum in order to educate and train students for the needs of today's hospitality industry as well as to anticipate the future needs of the industry.

- Measuring the performance of students' achievements is a helpful tool for iterative and interactive improvement of the theoretical education prior to the Management Shadowing Program. 
- Assessing the impacts of internships prior to the Management Shadowing Program is useful to ensure profitable internship experiences

- Understand the essential ingredients needed for a successful general manager in hospitality and increase the dose of these ingredients within the curriculum

The Management Shadowing Program has proven to be a practical and valuable tool to develop the managerial skills of prospective managers in the hospitality industry and a platform of cooperation where educators and sector practitioners both recognize the responsibility for developing and retaining talent for the tourism and hospitality industry.

Qualitative results support and enhance the findings that are listed above. The annex presents comparative means and standard deviations of all items in the closing questionnaire of the shadows and the managers. The closing questionnaire of the shadows and the managers look at the same phenomenon from angles 180 degrees apart and each party evaluates their own perspective. This cross evaluation enables the research to identify where the shadows and the managers mutually agree on an aspect and where the perceptions of the parties are different.

The first question of the closing evaluation regarding overall satisfaction of the shadows has a mean of 4,18 and the managers 4,53 which is a clear indication that the MSP has met the overall expectations of both the shadows and the managers. The questionnaire total mean for the shadows is 4,32 and for the managers is 4,44 which enhances the above mentioned finding of overall satisfaction from the Management Shadowing Program.

The outstanding findings of the Management Shadowing Program closing questionnaire are; $88 \%$ of the shadows (15 students) strongly agree with the question "I believe I did the right thing by participating in the Management Shadowing program" One student who graded 4 (agreed) with this question was the only student who had only one internship prior to the MSP and due to her academic achievement she was going to graduate with 7 semesters. The interview after the closing questionnaire with this student revealed that two internships are essential for quicker adaptation to work-place and work routines. The other student who graded this question 3 (neutral) was over experienced due to his long term working experience, not only during summer internships but also during winter months as a part time employee in the front office of a 5 star hotel. The post-closing interview with this student reveals that over experienced students have the expectation to "replace" the manager rather than to "shadow" the manager. This specific finding led to a more strict review of the prior experiences of prospective shadows in future years. The shadows must have an adequate level of experience in order to maximize the program benefits.

The placement process was found $42 \%$ highly successful, $53 \%$ successful and neutral by $6 \%$ of managers. The post-closing interview with the lower score responding managers reveal that managers are more eager to work longer period towards the summer as they invest in the shadows with future work expectation. The managers of 11 shadows (out of 17) who accepted the job offer from the host companies were more eager to participate in the MSP in the coming years (mean 4,59)

The evaluation of the shadows of their performance in proposing initiatives leading to revenue increase (M 3,76) or cost decrease (M 3,71) has received a higher score from managers (M 4,06 and M 3,94 respectively). Although these two items are below the neutral point of 3, compared to other aspects of the Management Shadowing Program these two questions are outstanding with the lowest score of the closing questionnaire. Post-closing interviews with the shadows and the managers leads to the improvement of the Management Shadowing Program in subsequent years with the pre-planned project to be pursued by the shadow in coordination with the manager. The General Managers of partner companies agreed to give the initiative to managers participating in the Management Shadowing Program for pre-agreed customer 
satisfaction, revenue increase and/or cost decrease projects. This improvement of the Management Shadowing Program requires the program instructor to meet with the partner companies prior to the placement process to develop alternative projects for each department in coordination with the partner company management, as these projects require top management commitment and alignment with top-down management objectives of the partner companies. This improvement shall be implemented in selected partner companies and the remaining partner company program shall be kept ceteris paribus to be able to assess the effectiveness of this new feature of the program

The Managers evaluation for question, "My shadow could use his/her time efficiently" with a mean of 4,65 is highly positive. The post-closing interviews with the shadows regarding time management skills showed that the shadows used real work experiences from the Management Shadowing Program for their projects for other courses and combined the Management Shadowing Program work with other courses as well. This combination led to efficiency in project work for other courses and enhanced interest in the Management Shadowing Program work from different perspectives. $77 \%$ of managers graded this question 5 (strongly agree) and $23 \%$ of the managers graded it 4 (agree). The post-closing interviews with the managers showed that the shadows were attentive and punctual to work and were enthusiastic to stay longer whenever needed. One of the shadows reported that he did not have time to go to lunch due to an overloaded check-in and check-out the same day and a team mate had brought sandwich and fruit for him. This experience was important for the shadow as it was evident that (i) he was needed; (ii) he was a member of the team and he was cared for; (iii) his work is recognized by the team. His report about this incident and post talks were quite sentimental. Seven of the shadows reported that they worked at home and delivered the results during the working days of the Management Shadowing Program. Five of the shadows reported that they want to spend more time in the partner company and insurance coverage for these students was increased to more than three days a week.

The managers strongly indicated that they enjoyed working with a young student $(\mathrm{M} 4,71)$ and benefited from the open minded approach of their shadow (M 4,53). The post-closing interview with the managers showed two aspects; (i) the energy and enthusiasm of the shadows was contagious for the other members of the department and (ii) that the basic questions of the shadows led to a re-evaluation of the current way of conducting business.

The shadows and the managers agree that the first introduction to the work environment as a "shadow manager" and not as an "intern" plays an important role in integration into the team and minimization of being perceived as potential threat to the current team members. The initiation period in a new company and a new team is the first challenge the shadow managers need to overcome. The shadows report that the more productive they are, the easier was the integration. $100 \%$ of the shadows encouraged future students to take the opportunity to participate in the management Shadowing Program and use it wisely, to be more proactive, to take the initiative, to remind the manager that they are not summer interns, and not to be shy to ask questions and to demand.

\section{Conclusions and Discussion}

The literature is rich regarding experiential learning, tourism education, mentoring, tourism internships, skills required for success in tourism and hospitality but, to the best of our knowledge, the combination of mentor protégé type of teaching and experiential learning at management level embedded in the curriculum of Tourism higher education is unheard of. There are several multinational hotel group's conducting internal management trainee and/or talent management programs, but these programs are after graduation and a longer term commitment with a higher cost to the company whereas the Management Shadowing Program 
is embedded into the curriculum enabling (i) the closer cooperation of academia and the sector practitioners casting a light on changing the sector requirements and enabling the faster adaptation of the curricula, (ii) the real time testing environment for the effectiveness of the curricula and with the prior internships leading to an increase in the internship experience enhancement. This iterative process keeps academia, sector practitioners and students in an active dynamic interaction leading to the evolution of the sector guided adaptation of the curricula as well as the cross polarization of best practices learned through theoretic education and from the summer internships. Sector HR managers are keeping closer contact with the prospective workforce and testing, discovering new ways of keeping the young and talented work force motivated. This study enables academicians to discuss and to evaluate the pros and cons of the Management Shadowing and/or similar programs available, but which have not been written about.

The results clearly indicate that students have understood and accepted the fact that the professional work life does not come with a syllabus or with a user manual. Taking the initiative to lead their career path is a major step towards management positions and an indication of a potential management career within few years.

The Management Shadowing Program has prior and post effects upon students. The prior effects are (i) more effective summer internships with the target of getting on the Management Shadowing Program at the internship company, (ii) loading prior spring semesters with more credits enabling less courses for the eighth semester for better time management in the Management Shadowing Program, (iii) establishing the mind-set for their careers before graduation. The post effects of the Management Shadowing Program are; (a) job offers, (b) demo version of real work experience providing a head start, (c) networking at managerial level, (d) a diploma with ready-to-work experiences (e) defining a career path.

One year after graduation post-contact with the shadows of the year 2017 has provided very positive feedback in that the Management Shadowing Program opened their minds, enlarged their vision and enabled their current positions. The 2018 shadows all received job offers from their host companies and from other companies in the hospitality industry. 4 accepted the job offers from other companies, 1 decided to continue for 6 months management program in Spain, 1 decided to start her own business, 11 accepted the job offers from the respective host companies. The placement rate after the Management Shadowing Program confirms that tourism graduates are willing to develop a career in the industry if they are given a managerial perspective. The Management Shadowing Program neither erases the discouraging experiences of the summer internships nor assures that world of perfection, but the Management Shadowing Program opens a window where the student sees the opportunity to make a change.

Contra Kuşluvan and Kuşluvan (2000), as well as Aksu and Kölsal (2005), who state the tourism students are falling away from the sector, the MSP proves that through a cooperative model between the sector, scholars and students, it is possible to develop and to retain talent within the Tourism Industry.

The findings from this research support the findings of Spanjaard et al. (2018) and Littlejohn, \& Watson, S. (2004) regarding the expectations of work-ready and career ready graduate expectation of the sector and, that MSP enables the testing of the wings of prospective managers, similar to time travel to the future managerial posts of the current students.

The competitive advantage of the Management Shadowing Program over other experiential learning opportunities, like summer internship, a sandwich year or management trainee programs, is providing the opportunity to build the management perspective above theoretical learning and prior to the summer internships. Gaining real life experiences at management level provides opportunities not only to use theoretical knowledge within different contexts, but also 
to base these experiences to summer internship experiences at a working level. Therefore the managerial perspective is an aggregation of class room learning, which also contains projects within the sector, and summer internship work experiences within the hospitality industry.

\section{Limitations}

Facilitating a program which requires the active involvement of sector practitioners is challenging and requires a foster instructor with solid sector experience. The fragility of the hospitality industry management team employment continuity shall be kept in perspective at all times and backup plans shall be kept updated and ready. During the second year implementation, two of the shadow managers are re-placed within the same company and one shadow manager is re-placed into another partner company. The transition requires careful planning and gentle communication, both with the shadow, the past/future manager and the past/future partner company.

Today's students do not like to be pulled by the leash; they require an illuminated path at least for the initial 2-3 weeks. Next year implementation requires pre-field work for the definition of the initial few weeks program and the learning objectives for the selected partner company and departments. Not all partner companies shall be nominated for the pre-defined initial week program to assess the effectiveness of this modification.

Future applications of the Management Shadowing program shall try to cast a light on why students did not, or could not, attend the Management Shadowing Program. The following questions remain open until the next implementation: were the students willing to participate but could not and why, or were the students not interested in the program and why? Also the paired sample t-test method can be utilized to asses (i) how much the sector contributes to the development of skills and (ii) how much graduates benefit from the program for developing their managerial skills. Also the qualifications listed in the job vacancy shadow manager announcement and the recruited candidates qualifications shall be compared to evaluate how reliable the job vacancy announcement qualifications are in actual recruitment. Longitudinal observation of the career development of the shadow managers compared to students not participating in the program and the impact of the Management Shadowing Program in the careers of participants form another aspect for research. 


\section{REFERENCES}

Aksu A. A. \& Köksal D. C. (2005). "Perceptions and Attitudes of Tourism Students in Turkey”. International Journal of Contemporary Hospitality Management 17/5 (2005) 436-447.

Anafarta N. \& Cizel B. (2003). “Career Analysis in tourism Industry: Experiences from Turkey”. Tourism Review 58/3 (2003) 15-19.

Bower G. G. (2014). “Theory and Practice: Utilizing Dewey's Experiential Learning Theory to Implement a 5k Road Race”. Journal of Hospitality, Leisure, Sport \& Tourism Education 15 (2014) 61-67.

Ceylan D. (2017). “Management Shadowing”. II. International Conference on Tourism Dynamics and Trends Proceeding Book (2017) 423-424. Seville.

Chickering A. (1977). “Experience and Learning: An Introduction to Experiential Learning”. Rochelle (1977) 73-75.

Counts G. S. (1978). Dare the School Build a New Social Order?. USA 1978.

Daskin M. (2016). “Tourism Students' Career Conceptions Towards Service Industry Profession: A Case Study from Human Resource Perspective”. Middle East J. Management 3/1 (2016) 19-33

Dewey J. (1938). Experience and Education. New York 1938.

Elo S., Kääriäinen M., Kanste Q., Pölkki T., Utriainen \& Kyngäs H. K. (2014). “Qualitative Content Analysis: A Focus on Trustworthiness”. SAGE Open, DOI: 10.1177/2158244014522633 sgo.sagepub.com

Garavan T., O’Brien F. \& O’Hanlon D. (2006). “Career Advancement of Hotel Managers Since Graduation: A Comparative Study”. Personnel Review 35/3 (2006) 252-280.

Gunbayi I. (2018). "Developing a Qualitative Research Manuscript Based on Systematic Curriculum and Instructional Development”. European Journal of Social Sciences Studies 3/3 (2018) 124-153.

Huang Y.-L., \& Lin C.-T. (2010). "Management Trainee Core Competencies in the Hospitality Industry: Differences Between Managers and Scholars”. Journal of Human Resources in Hospitality \& Tourism 10 (2010) 1-13.doi:10.1080/15332845.2010.500166

Kolb D. A. \& Lewis L. H. (1986). “Facilitating Experiential Learning: Observations and Reflections”. New Directions for Continuing Education 30 (1986) 99-107.

Kusluvan S. \& Kusluvan Z. (2000). "Perceptions and attitudes of undergraduate tourism students towards working in the tourism industry in Turkey”. Tourism Management 21 (2000) 251-269.

Lincoln S. Y. \& Guba E. G. (1985). Naturalistic Inquiry. Thousand Oaks 1985.

Littlejohn D. \& Watson S. (2004). “Developing Graduate Managers for Hospitality and Tourism”. International Journal of Contemporary Hospitality Management 16/7 (2004) 408-414. https://doi.org/10.1108/09596110410559096

Mabey C. (2002). “Mapping Management Development Practice”. Journal of Management Studies 39/8 (2002) $1139-1160$.

Martin D. \& McEvoy B. (2003). "Business Simulations: A Balanced Approach to Tourism Education”. International Journal of Contemporary Hospitality Management 6 (2003) 336-339.

McEwan B. (1995). “On the Road to Quality”. Insider 12/4 (1995) 44-47.

McKercher B., Williams A. \& Coghlan I. (1995). “Career Progress of Recent Tourism Graduates”. Tourism Management 16/7 (1995) 541-545. https://doi.org/10.1016/0261-5177(95)96807-U

Miettinen R. (2000). "The Concept of Experiential Learning and John Dewey's Theory of Reflective Thought and Action”. International Journal of Lifelong Education 19/1 (2000) 54-72.

Mullins L. J. (1993). “The Hotel and the Open Systems Model of Organisational Analysis”. Service Industries Journal 13/l (1993) 1-16.

Polit D. F. \& Beck C. T. (2012). Nursing Research: Principles and Methods. Philadelphia 2012.

Purcell K. \& Quinn J. (1996). "Exploring the Education-Employment Equation in Hospitality Management: A Comparison of Graduates and HNDs”. International Journal of Hospitality Management 15/1 (1996) 51-68.

Raybould M. \& Wilkins H. (2005). “Over Qualified and under Experienced”. International Journal of Contemporary Hospitality Management 17/3 (2005) 203-216. doi:10.1108/09596110510591891

Roney S. A. \& Oztin P. (2007). "Career Perceptions of Undergraduate Tourism Students: A Case Study in Turkey, Journal of Hospitality”. Leisure, Sport and Tourism Education 6/1 (2007) 4-17.

Spanjaard D., Hall T. \& Stegemanna N. (2018). "Experiential Learning: Helping Students to Become 
‘Career-Ready”. Australasian Marketing Journal 26 (2018) 163-171.

Unur K. \& Köşker H. (2015). “Türkiye'de Turizm Eğitimi Ve Turizm Eğitimi Alan Öğrencilerin Turizme Bakış Açılarına Yönelik Araştırmaların Incelenmesi”. Cag University Journal of Social Sciences 12/1 (2015) 44-71.

Wexley K. N. \& Baldwin T. T. (1986). “Management development”. Journal of Management 12/2 (1986) 277-294.

Zopiatis A. \& Theocharous A. L. (2013). "Revisiting Hospitality Internship Practices: A Holistic Investigation”. Journal of Hospitality, Leisure, Sport \& Tourism Education 13 (2013) 33-46. doi:10.1016/j.jhlste.2013.04.002 